\title{
Public Inscriptions and Manchu Language Reform in the Early Qianlong Reign (1740s-1760s) ${ }^{1}$
}

\author{
MÅRTEN SÖDERBLOM SAARELA \\ Institute of Modern History, Academia Sinica
}

Official signs and steles in the Qing empire were often at least bilingual, with Manchu and Chinese either side by side or on opposite sides. New institutions and renovated buildings necessitated new Manchu words and turns of phrase for the accompanying inscriptions. Under the Qianlong emperor, the text that should go on plaques and steles was carefully scrutinized, especially regarding the use of Manchu vocabulary. Public inscriptions thus involved watchful editing. The emperor was not the only driving force behind the reform. In part, individuals who moved through Beijing and Manchuria saw the words inscribed in the built-up environment around them change because officials in the field had memorialized the throne to draw attention to usages that the initial reform had missed. This paper will discuss this process.

\author{
乾隆初年間的官方碑刻與滿文改革 \\ Mårten Söderblom Saarela 馬騰 \\ 中央研究院近代史研究所 \\ 摘要
}

清朝官方頒布的㻞額和碑文經常會使用至少兩種語言，即同時將滿文與漢文 書寫在碑面同側或對側。這一規定導致在創制政府機構或翻修官舍時，常常 需要創造新的滿文詞彙或辭句用於碑銘之上。乾隆皇帝在位前期對牌骗及碑 文中的滿文使用進行了嚴格的審查，特別注重詞彙的正確使用，而同時期的

1. I first discussed some of the sources introduced here at the workshop "Multilingual and Multimedia Translation in Qing China" at the University of California, Berkeley, in June 2018. A version of the paper proper was presented at the 22nd Biennial Conference of the European Association for Chinese Studies in Glasgow in September 2018. I thank the organizers and those who listened and commented on these occasions. I'm especially grateful to Alice Crowther for her invitation to write a paper on Manchu epigraphy in the first place and for directing me to relevant sources. Research in Beijing in 2017 was funded by the Max Planck Institute for the History of Science and facilitated by Qiu Yuanyuan, and in 2019 by a grant (108-2410-H-001-078) from the Ministry of Science and Technology, R.O.C. (Taiwan). Kjell Ericson, Lai Yu-chih, and Yulian Wu kindly shared materials, and Eric Schluessel and José Andrés Alonso de la Fuente helped with the etymologies. 
大量新創碑文則是這審慎的訂正過程之結果。需要注意的是, 乾隆皇帝並非 推動滿文改革的唯一動力, 而是地方官員在施政過程中發現滿文使用不規範 之處繼而上奏, 使得從北京到盛京作為公共景觀的碑刻得以一體改觀。本文 即探討這一歷史過程。

In Beneath the Red Banner (Zhenghong qi xia 正紅旗下), Lao She's 老舍 (1899-1966) unfinished novel about Manchu life in Beijing around the turn of the twentieth century, there is a famous passage that deals with one of the protagonists' language skills. Cousin Fuhai-a kindhearted housepainter with many talents- has a very poor command of Manchu. Lao She's narrator informs the reader that this particular Manchu only ever spoke and wrote Chinese. In addition, Fuhai's unfamiliarity with Manchu affected how he interacted with writing in the environment around him:

When he came upon a ceremonial plaque or stone inscription written in both Manchu and Chinese, he could appreciate the elegance or boldness of the Chinese characters, but he would only glance at the Manchu words out of the corner of his eye, as if he reverently wanted to maintain his distance.

当他看到满、汉文并用的㻞额或碑碣, 他总是欣赏上面的汉字的秀丽或刚 劲，而对旁边的满字便只用眼角照顾一下，敬而远之。2

Lao She's point is that a late Qing bannerman like Fuhai, without any hope of obtaining an official appointment, did not know Manchu. What is interesting for the purposes of this paper, however, is that the passage shows that Manchu inscriptions were part of the urban landscape of Beijing. If that was the case around the turn of the twentieth century, when the novel is set, it was even more so in the eighteenth, when many Manchu steles and inscribed plaques were erected or installed along with the construction or renovation of temples and official buildings. On the eve of the Boxer Rebellion, those who like Fuhai walked through the Qing capital would have chanced upon mostly older Manchu steles and inscribed tablets and plaques. A century and a half earlier, however, city dwellers could gaze at new inscriptions. Indeed, the thenreigning Qianlong emperor was erecting Manchu steles for bannermen to read. ${ }^{3}$

As a part of the public image of the Qing government, official signs and stele were often at least bilingual, with Manchu and Chinese either side by side or on opposite

2. Lao She 老舍, Zhenghong qi xia; Er Ma 正红旗下 二马, Lao She wenji (1961-1962; repr., Chongqing: Chongqing chubanshe, 2017), 32; Translation from Lao She, Beneath the Red Banner, trans. Don J. Cohn (Beijing: Panda Books, 1982), 51 with some modifications.

3. Chuang Chi-fa 莊吉發 [Zhuang Jifa], “manju hergen - manju gisun—Manzhou yuwen zai Qingchao lishi wutai shang suo banyan de juese” manju hergen - manju gisun一滿洲語文在清朝歷史舞臺上所扮演的角色, in Qingshi lunji 清史論集, vol. 23 (Taipei: Wen shi zhe chubanshe, 2013), 286. 
sides. Since stele were often erected to commemorate recent events, recently deceased servants of the throne, or in order to mark the completion of a construction project, their inscriptions reflected the development of the Qing from a small frontier state to a great empire. New institutions and renovated buildings necessitated new Manchu words and turns of phrase for the accompanying inscriptions.

Initially, the language of steles does not appear to have posed a problem to those who wrote the inscriptions. Steles, so prominently used in China since antiquity, were initially simply referred to in Manchu using the Chinese name bei 碑 or prosaically as "stone documents" (uwehei bithe). Eventually, however, a Manchu terminology developed. Not only did the steles themselves receive the new name of "shining stones" (eldengge wehe), but the institutions commemorated through steles and the places identified with plaques received new names as well. From at least the 1740s, under the Qianlong emperor, the archival record shows that the text that should go on plaques and steles was carefully scrutinized, especially regarding their use of Manchu vocabulary. Public inscriptions thus not only involved logistical and financial considerations and technical skill, but also watchful editing.

The Qianlong emperor initiated or continued several major Manchu literary projects, including the compilation of new reference works and the translation of Buddhist and Confucian texts into Manchu from Mongolian and Chinese. In the process, the Manchu lexicon was revised, and words considered Chinese loans were removed and replaced with new coinages. Often, the new expressions mimicked the Chinese in their semantic structure, but not in their form, which appears to have been what mattered most to the reformers.

Qianlong's reform of the Manchu lexicon has attracted the attention of researchers for some time. Outside the Qing empire, lexicographers such as Ivan Ilyich Zakharov (1816-1885) noted the hundreds of neologisms introduced in Qianlong's official Manchu-Chinese dictionary Han-i araha nonggime toktobuha manju gisun-i buleku bithe |Yuzhi zengding Qingwen jian 御製增訂清文鑑 (Imperially commissioned mirror of the Manchu language, expanded and emended) from 1772-1773. ${ }^{4}$ Erwin von Zach (1872-1942) described the structure of many of the new words, ${ }^{5}$ which he later called "artificial creations of the emperors" (Kunstprodukte der Kaiser). ${ }^{6}$ Peter Schmidt (1869-1938) offered more context when he called these "phonetically and orthographically unjustifiable" words the products of the "ardent linguistic purism" (Sprachreiningungseifer) of Qianlong's court scholars. ${ }^{7}$

4. Ivan Il'ich Zakharov, "History of the Manchu Language, from the Preface to Professor I. Zacharoffs Manchu-Russian Dictionary, 1875 [Part 2]," translated by M. F. A. Fraser, The Chinese Recorder 22, no. 4 (1891): 152.

5. Erwin Ritter von Zach, "Ueber Wortzusammensetzungen im Mandschu," Wiener Zeitschrift für die Kunde des Morgenlandes 11 (1897): 245.

6. Erwin von Zach, "Einige Ergaenzungen zu Sacharow's Mandžursko-russki slovarj," Mitteilungen der deutschen Gesellschaft für Natur- und Völkerkunde Ostasiens 14, no. 1 (1911): 2. My overview in these paragraphs does not attempt to list all mentions of the neologisms in the scholarly literature.

7. P[eter] Schmidt, "Chinesische Elemente im Mandschu. Mit Wörterverzeichnis," Asia Major, first series, 7 (1932): 574. 
Until the late twentieth century, discussions of the new words were based primarily on Qianlong's Manchu-Chinese dictionary. Increased access to various kinds of archival collections changed this situation. Notably, Zhang Hong, Cheng Dakun, and Tong Yonggong published archival sources that showed how the reform unfolded over many years before the publication of Qianlong's bilingual dictionary. ${ }^{8}$ Even though Pamela Crossley and Evelyn Rawski initially contextualized Qianlong's "language purification" as part of a greater state-building project that they argued went back to pre-conquest times, ${ }^{9}$ Rawski later discussed it in more specific terms on the basis of Zhang, Cheng, and Tong's reprinted archival sources. ${ }^{10}$ Mark Elliott associated it to the emperor's view of language as essential to the maintenance of Manchu identity and his attendant fear of Manchu language attrition. ${ }^{11}$ These scholars also noted the reform's links to the aforementioned major translation projects undertaken at court. However, the reform has yet to be studied in its full extent.

This paper will contribute to the literature on Qianlong's language reform by looking at how it played out in the field of public inscriptions. I will show that the emperor was not the only driving force behind the reform. Individuals who moved through Beijing and Manchuria saw the words inscribed in the built-up environment around them change in part because officials in the field had memorialized the throne to draw attention to usages that the initial reform had missed. Rather than stress the link between discussions of vocabulary and Manchu identity or imperial ideology, I will focus on the choices and difficulties that reformers faced in specific cases. The paper will thus discuss this process of, as it were, the steles' hundred visions and revisions (before the taking of a toast and tea).

First, I will give a brief overview of the erection of Manchu stele since the preconquest period. Second, I will discuss a few examples of stele and inscriptions in the context of Qianlong-era language reform. My key sources are the endorsed originals and file copies of Manchu palace memorials (Manwen zhupi zouzhe 滿文硃批奏摺 and Manwen lufu zouzhe 滿文錄副奏摺) and Manchu court letters recorded in copy books (dangbu 檔簿) and held at the First Historical Archives in Beijing, supplemented by reprinted edicts, memorials, stele rubbings, and visual sources. These sources, while informative, unfortunately do not allow me to say much about how the public Manchu inscriptions were received. What I will offer here are the stele inscriptions as discussed by the emperors and officials responsible for them.

8. I will use and cite these reprinted sources later in the paper.

9. Pamela Kyle Crossley and Evelyn S. Rawski, "A Profile of the Manchu Language in Ch'ing History," Harvard Journal of Asiatic Studies 53, no. 1 (1993): 82-83.

10. Evelyn S. Rawski, The Last Emperors: A Social History of Qing Imperial Institutions (Berkeley: University of California Press, 1998), 37-38.

11. Mark C. Elliott, Emperor Qianlong: Son of Heaven, Man of the World (New York: Longman, 2009), 56-58. 


\section{Background: Manchu Steles and Public Inscriptions}

Steles erected in pre-conquest Manchuria included the kinds later put up in Beijing. The early Manchu rulers recognized the role of steles as public pronouncements of policy. In 1608, Nurhaci erected a stele (uwehei bithe, "stone document"; uwehe ilibuha gisun, "words established in stone" [old spelling uwehe > new spelling wehe]) ${ }^{12}$ on the MingJurchen border that announced that trespassing from either side should be punished by death. Ming officials came from Liaodong to confirm this policy through an oath and the sacrifice of a white horse. Nurhaci considered the end to Jurchen trespassing to be one of his great achievements. Nurhaci and Hong Taiji repeatedly referenced this stele while claiming that the Ming failed to heed its words and secure the border (one of the "seven grievances" that Nurhaci directed to the Ming). The stele's intended readership was not the commoners of either side of the border, but the authorities. The stele stood as a testament-a public proof-to a cross-border agreement. ${ }^{13}$

Yet as the early Qing state expanded, inscriptions appeared in more visible locations. The gates to the walled towns that came under Manchu rule received Manchu names that were carved on plaques. Any literate traveler would have been able to read these public inscriptions. ${ }^{14}$

Furthermore, steles continued to be important in the early Qing state's foreign relations. In 1638-1639, after the second Manchu invasion of Korea, a trilingual (Manchu, Mongol, Chinese) stele was erected in Korea and written in the voice of the Koreans ("our small country" [meni ajige gurun]). The Qing side provided the Koreans with the Manchu original. The Chosŏn side then translated it into Chinese and repeatedly

12. Kicentai 庄声 [Zhuangsheng], Teikoku o tsukutta gengo seisaku: Daichin gurun shoki no gengo seikatsu to bunka 帝国を創 った言語政策—ダイチン グルン初期の言語生活と文化 (Kyōto: Kyōto daigaku gakujutsu shuppankai, 2016), 61 writes that it was also referred to as a šibei following the Chinese shibei 石碑.

13. The chronicle does not mention the language in which the stele was inscribed. Quotations from the stele are similar but not identical. They can represent paraphrases of an underlying Manchu text, but I do not think it can be excluded that they constitute ad hoc translations from the Chinese, which would then, it follows, have been the language of the stele inscription.

The stele is mentioned in Guang-lu 廣祿 and Li Xuezhi 李學智, trans., Qing Taizu chao lao Manwen yuandang: Di yi ce “buang” zi lao Manwen dangce 清太祖朝老滿文原檔: 第一冊荒字老滿文檔冊 (Taipei: Taiwan zhonghua shuju, 1970), 8-9 (uwehei bithe), 38-39 (where the Chinese want to redraw the border and erect a new stele, later invoked as one of the "seven grievances"), 64-66 and 79-80 (where the failure to heed the original stele is one of the "grievances"); Guang-lu 廣祿 and Li Xuezhi 李學智, trans., Qing Taizu chao lao Manwen yuandang: Di er ce “ze” zi lao Manwen dangce 清太祖朝老滿文原檔：第二冊员字老滿文檔冊 (Taipei: Taiwan zhonghua shuju, 1970), 31-32, 49, 216-18 (again as one of the “grievances”); Jiu Manzhou dang yizhu: Qing Taizong chao (yi) 舊滿洲檔譯註: 清太宗朝（一) (Taipei: Guoli gugong bowu yuan, 1977), 2 (item 2566) and 162 (Chinese translation), 129 (item 2941 [uwehe ilibuha ...]) and 241 (Chinese translation).

Mentions of the stele in derivative chronicles include Zhongguo di yi lishi dang'an guan 中国第一历史档案馆, trans., Qing chu nei guoshi yuan Manwen dang'an yibian 清初内国史院满文档案译编 (Beijing: Guangming ribao chubanshe, 1989), vol. 1, 70-71 (Chinese translation only).

Nurhaci on having secured the border: Tatiana A. Pang and Giovanni Stary, Manchu versus Ming: Qing Taizu Nurhaci's "Proclamation to the Ming Dynasty" (Wiesbaden: Harrassowitz, 2010), 27-28.

14. Kicentai, Teikoku o tsukutta gengo seisaku, 62. 
revised it before they were able to satisfy the Qing side. The stele was simply called bei in Manchu, using the Chinese word ("took a stone and erected a stele" [wehe be gajifi bei ilibufi]). ${ }^{15}$

Sometimes temples and stele were erected together as elements of foreign policy. At the site of a new temple, Hong Taiji in 1630 (Tiancong 4) erected a Manchu-Chinese stele to commemorate a Tibetan cleric who died in 1621 en route to Manchuria. The Manchu text is written in the old, unreformed script. ${ }^{16}$

In 1638 (Chongde 3), Hong Taiji dedicated a temple a few li west of Mukden and gave it the name Yargiyan etehe fucihi [fujihi? $]^{17}$ soorin (Ch. Shisheng Si 實勝寺), "Buddha throne (i.e. temple) of true victory." Two stele were erected at the site. One of them carried a Manchu text, which called the inscribed stele wehei bei $[<$ Ch. bei 碑] de araha bithei gisun, "Words in text written on a stone stele." 18 The fact that the other languages included Mongolian and Tibetan shows that this temple too was part of the Qing policy toward the Buddhist Mongols. ${ }^{19}$

The court continued to erect steles in the post-conquest period. A new name was introduced to refer to steles. In 1708, the preface to the normative dictionary Han-i araha manju gisun-i buleku bithe (Imperially commissioned mirror of the Manchu language) called them "shining stones" (eldengge wehe), ${ }^{20}$ a word that caught on and became standardized as the Manchu name for steles from 1749 at the latest. ${ }^{21}$ The preface to the dictionary was nominally composed by the Kangxi emperor. It does indeed appear that the emperor himself came up with the new coinage. A draft version of the preface used the phrase "stele stones" (bei wehe). The emperor's vermillion brush crossed out the Chinese loan bei and replaced it with eldengge "shining." 22

Often, the occasion for erecting a stele was the commemoration of deceased im-

15. Walter Fuchs, "Early Manchurian Inscriptions in Manchuria,” The China Journal 15 (1931): 7 (who gives the date 1640); Ch’oe Hak-kŭn 崔鶴根, “Sowi 'Samjŏndo' ŭi Manmun pimun chuyŏk” 所謂「三田渡碑」의 滿文碑文 註譯, in Chŭngbo Altaiŏhak non'go: Munhŏn kwa munbŏp 增補알타이語學論放一文獻과 文法一, ed. Yi Hŭi-sŭng 李熙昇 (Seoul: Pogyŏng munhwasa, 1989), 8-37, esp. 8-9, 30-31; Sŏng Paeg-in 成百仁, “Samjŏndo-bi Manjumun” 三田渡 碑 滿洲文, Tong’a munhwa 東亞文化 9 (1970): 117-48; Zhongguo di yi lishi dang'an guan, Qing chu nei guoshi yuan Manwen dang'an yibian, vol. 1, 441 (Chongde 4/11/6, 1639/11/30), 448-49 (Chongde 4/12/28, 1640/1/20).

16. Oshibuchi Hajime 鴛淵一, Manshū hiki kō 満洲碑記考 (Tōkyō: Meguro shoten, 1943), 57-70; Fuchs, “Early Manchurian Inscriptions," 7; Tak-Sing Kam, “The Sino-Manchu Inscription of 1630 in Honour of the Uluk Darxan Nangsu Lama," International Journal of Central Asian Studies 4 (1999): 217-40; Beijing tushuguan 北京圖書館, Beijing tushuguan cang Zhongguo lidai shike taben huibian 北京圖書館藏中國歷代石刻拓本匯編 (Zhengzhou: Zhengzhou guji chubanshe, 1989-1991), vol. 61, 1 (not legible to my eye).

17. Fuchs, "Early Manchurian Inscriptions," 7.

18. Oshibuchi, Manshū hiki kō, 135.

19. Zhongguo di yi lishi dang'an guan, Qing chu nei guoshi yuan Manwen dang'an yibian, vol. 1, 354-57 (Chongde 3/8/12, 1638/9/19); Taizong Wen huangdi shilu 太宗文皇帝實錄, Qing shilu (Beiijing: Zhonghua shuju, 1986), vol. 2, 565 (Chongde 3/8/renyin, 1638/9/19).

20. Han-i araha manju gisun-i buleku bithe (Beijing: Wuying dian, 1708), sioi:6a-b.

21. It is referred to as the new standard term in a Manchu court letter addressed to the grand secretaries and chamberlains of the imperial bodyguard and dated Qianlong 14/7/17 (1749/8/29), recorded in copy-book 03-18-009-000008-0002, FHA.

22. The draft preface is found among the endorsed Manchu palace memorials, 04-02-002-000080-0007, FHA. 
perial princes or banner servants of the throne. ${ }^{23}$ Furthermore, officials petitioned the throne to be allowed to put up such stele. ${ }^{24}$

Erecting steles could be a complicated process, especially in the radically enlarged post-1644 empire. When a stele was to be erected in the provinces in the emperor's handwriting, officials in the field had to communicate the size of the stone to the capital. Furthermore, the individuals on site might in reality be better placed than the emperor to actually compose the text of a stele to be erected near a local institution such as a temple. A back-and-forth with Beijing over the final wording was sometimes the result. ${ }^{25}$ Carvers, whose job was not easy, might also have to be dispatched from the capital. The paper carrying the manuscript for the inscription could get wet from humidity, which affected the appearance of the characters written on it. Transposing them accurately to the stone was difficult. If revisions were needed, the carver might have to remain on site for more than a month. ${ }^{26}$ Upon completion of the stele (as of 1711 still called bei in Manchu), the original manuscript ( $d a$ araha bithe) might even have to be sent back to Beijing. ${ }^{27}$

Having the text of older inscriptions on hand in Beijing was evidently useful. In 1761 (Qianlong 26/2/13, 1761/3/19), after the conquest of what is now Xinjiang, Agūi (1717-1797) reported from the field that a set of two steles erected in Ghulja (Ma. Gūlya, in Ili) had sustained damage, "erasing the inscribed text so that it is no longer legible" (ede wehe de foloho hergen mahülabufi tuwame turibume muterakū). Agūi requested that "the draft texts for these two stele be written out again and sent over for them to be carved again onto the original stone inscription by Fukui, who did the work in the first place" (ere juwe eldengge wehe-i bithei jise be dasame arabufi unggihe manggi, da weilehe fukui de nikebufi dasame weilebuki seme wesimbuhebi,). Qianlong agreed to copy out the "quadrilingual draft" (duin hacin-i hergen jise)—probably Manchu, Mongolian, Tibetan, and Chinese (if not Oirat) — and send it out to Xinjiang for recarving. ${ }^{28}$

23. E.g., Zhongguo di yi lishi dang'an guan, Qing chu nei guoshi yuan Manwen dang'an yibian, vol. 3, 49 (Shunzhi 6/10/10, 1649/11/13), 372 (Shunzhi 14/10/22, 1657/11/27), 386 (Shunzhi 15/12/4, 1658/12/27; two steles with epitaphs were erected on this day).

24. That is how I interpret the account of the stele in Zhongguo di yi lishi dang'an guan, Qing chu nei guoshi yuan Manwen dang'an yibian, vol. 3, 4 (Shunzhi 6/1/9, 1649/2/19). Kangxi apparently denied at least some such petitions on the grounds that erecting a stele was not as good as historiographically recording a person's life, which assured transmission to posterity: Zhongguo di yi lishi dang'an guan 第一历史档案馆, ed., Kangxi chao Manwen zhupi zouzhe quanyi 康熙朝 满文朱批奏折全译 (Beijing: Zhongguo shehui kexue chubanshe, 1996), 304 (item 564, Kangxi 42/12/9, 1704/1/15).

25. Zhongguo di yi lishi dang'an guan, Kangxi chao Manwen zhupi zouzhe quanyi, 398 (item 819, Kangxi 44/12/7, 1706/1/21).

26. Zhongguo di yi lishi dang'an guan, Kangxi chao Manwen zhupi zouzhe quanyi, 386 (item 780, Kangxi 44/8/19, 1705/10/6), 394 (item 806, Kangxi 44/11/6, 1705/12/21), 455-66 (item 968, Kangxi 45/8/16, 1706/9/22).

27. I think that the implication is that the original document with the emperor's handwriting was not destroyed during carving: Guoli gugong bowuyuan 國立故宮博物院, ed., Gongzhong dang Kangxi chao zouzhe 宮中檔康熙朝奏摺 (Taipei: Guoli gugong bowuyuan, 1976-1977), vol. 9, pt. 2, 179-80 (item 300, Kangxi 50/9/27, 1711/11/7); Chinese translation in Chuang Chi-fa 莊吉發 [Zhuang Jifa], trans., Sun Wencheng zouzhe 孫文成奏折 (Taipei: Wen shi zhe chubanshe, 1978), 40 (item 82); Zhongguo di yi lishi dang'an guan, Kangxi chao Manwen zhupi zouzhe quanyi, 748 (item 1802).

28. Zhongguo di yi lishi dang'an guan 中国第一历史档案馆, Qianlong chao Manwen jixin dang yibian 乾隆朝满文寄信档 译编 (Changsha: Yuelu shushe, 2011), vol. 2, 113 (item 54). 
A decision taken a few years later reveals the particular difficulties involved in carving Manchu steles. In 1764 or earlier (before Qianlong 29/11/25, 1764/12/17), it was decided that steles should be put up at government schools across China proper to celebrate the victory in Xinjiang. Similar steles had been erected in the past to celebrate military victories. Suldei 蘇爾德 (fl. 1757-1778), financial commissioner in Jiangsu, had seen that in Suzhou, the Manchu versions of those past inscriptions (of texts dating from 1729 and 1754) "contained many mistakes in the brush strokes of the Manchu characters” 所鏶清字筆畫多有訛錯. Suldei corrected the mistakes. In order to prevent similar mistakes in the new inscription, he sent a bannerman to oversee its carving. The idea was that rubbings of the new stele should then be sent to five other locations in the province where identical steles would be erected. Yet because of the sheer size of the original, it was difficult in some places to source a stone of the right size and to find a location that could support it. Suldei proposed that the layout and size of the stele should be modified according to local needs and that "banner personnel literate in Manchu" 通曉清文旗員 be dispatched to trace the Manchu text in each case, thus replicating the process he had carried out for the first of the new inscriptions. ${ }^{29}$

The arrangement that Suldei proposed was probably costly. The court decided (Qianlong 29/12/jiashen, 1764/12/29) that since "the literati of the outer provinces have never been proficient in the dynastic script, there is also no need to order it carved on the steles” 至外省士子, 本不諳習國書, 碑內亦可冊庸令其鑴刻. ${ }^{30}$ Thus the erection of Manchu steles in the south was dispensed with, and no banner official had to be sent to supervise each carving.

In the case of Chinese steles, readers of the inscriptions were not limited to those who saw the original stone in person, but it is not obvious to what extent that was the case for Manchu steles. Rubbings of some stele were indeed very widely distributed. In 1705, Kangxi's inscription on the pacification of the Northwest was reproduced in ten thousand copies, yet it is unclear in what languages. ${ }^{31}$ Furthermore, the texts of imperial steles were recorded in local gazetteers, ${ }^{32}$ but probably in Chinese only. Finally, when couriers who carried an imperially authorized text for a stele inscription passed through a location, local officials might greet the party in a ceremony. ${ }^{33}$ I assume that such events drew crowds. Perhaps such assemblies of the curious got a glimpse of the Manchu text on a blueprint sent from Beijing, but I do not think that the Manchu text would have been read out aloud for them.

29. Guoli gugong bowuyuan 國立故宮博物院, ed., Gongzhong dang Qianlong chao zouzhe 宮中檔乾隆朝奏摺 (Taipei: Guoli gugong bowuyuan, 1982-1988), vol. 23, 297-98.

30. Gaozong Chun huangdi shilu 高宗純皇帝實錄, Qing shilu (Beijing: Zhonghua Shuju, 1986), vol. 17, 1067-68.

31. Zhongguo di yi lishi dang'an guan, Kangxi chao Manwen zhupi zouzhe quanyi, 366 (item 722, Kangxi 44/intercalary 4/10, $1705 / 6 / 1)$.

32. Zhongguo di yi lishi dang'an guan, 394 (item 807, Kangxi 44/11/6, 1705/12/21).

33. Zhongguo di yi lishi dang'an guan, 568-69 (item 1268, Kangxi 47/3/23, 1708/4/13). 


\section{Public Inscriptions and Qianlong-Era Language Reform}

Reproductions of Manchu steles did not have the circulation that Chinese stele rubbings and transcriptions did, but still, many Manchu steles were erected and available for viewing, especially in Beijing. Restored or newly founded temples, for instance, required a public stone inscription. Not all of them were even erected on government initiative; seven temple steles with Manchu inscriptions written by individual officials, religious organizers, or anonymous bannermen are known from Beijing. ${ }^{34}$

The vocabulary used in Beijing temple stele differed. For example, the stele for Fahai Si 法海寺, erected in 1660 in the suburbs of Beijing, called the temple Fa hai sy juktehen, where the last element is new word for "temple" and the first three elements are transcriptions of the Chinese name. ${ }^{35}$ The old name, "Buddha throne" (fucihi soorin), was after 1645 no longer used for what in Chinese was called $s i .^{36}$ The change in name caused an asymmetry between Manchu and Chinese nomenclature. The new Manchu name juktehen was also used to translate Chinese miao 廟, which referred to a Confucian temple, thus constituting an alternative to the transliterations miyoo and miyo often used to render Chinese miao in Manchu. However, at times Manchu miyoo, from the Chinese word for Confucian temple, translated Chinese $s i$, a word that was most often (but not always) used for Buddhist temples. An altar, tan 壇 in Chinese, was as of 1685 simply called tan in Manchu. ${ }^{37}$ In the Qianlong period, such public inscriptions in Manchu were subjected to official scrutiny and in some cases reform.

Under Qianlong, Manchu steles continued to be erected in the same contexts as before. However, unlike for earlier periods, there is a great deal of evidence to suggest that, in this period, the Manchu wording used in public inscriptions did not represent an ad hoc problem to be solved by whoever wrote the text. Rather, officials scrutinized the wording of Manchu steles and petitioned the emperor to standardize it. Thus Qianlong-era Manchu language reform, most famously represented by the imperially authorized lexicographical collections that were published at the Beijing palace, entered the public space. Not only officials, clerks, and banner students for the translation examination were exposed to Manchu neologisms and reformed expressions, but so was

34. Guan Xiaojing 关笑晶, “Qing qianqi Beijing simiao Manwen bei chutan” 清前期北京寺庙满文碑初探, in Manxue luncong 满学论从, ed. Zhao Zhiqiang 赵志强, vol. 4 (Shenyang: Liaoning minzu chubanshe, 2014), 191-93.

35. Beijing tushuguan, Beijing tushuguan cang Zhongguo lidai shike taben huibian, vol. 61, 150-51; Beijing shi minzu guji zhengli chuban guihua xiaozu bangong shi Manwen bianji bu 北京市古籍整理出版规划小组办公室满文编辑部, ed., Beijing diqu Manwen beike tapian zongmu 北京地区满文碑刻拓片总目, Beijing diqu shaoshu minzu guji mulu congshu 6 (Shenyang: Liaoning minzu chubanshe, 2015), item 628. The temple ruins are photographed in Liu Xiaomeng 刘小 萌, Qingdai Beijing qiren shehui 清代北京旗人社会 (Beijing: Zhongguo shehui kexue chubanshe, 2008), 75 (figure 33).

36. It is seen on a stele from 1645: Mark C. Elliott, "Turning a Phrase: Translation in the Early Qing Through a Temple Inscription of 1645," in Historische und bibliographische Studien zur Mandschuforschung, ed. Martin Gimm, Giovanni Stary, and Michael Weiers, Aetas Manjurica 3, 1992, 33.

37. Beijing shi minzu guji zhengli chuban guihua xiaozu bangong shi Manwen bianji bu, Beijing diqu Manwen beike tapian zongmu, items 274, 634, 664 . 
anyone who took the time to look over new stele that went up around the capital's temples and altars. In the following sections, I will look at, first, the names for places and institutions and, second, at a discussion about the translation of Buddhist vocabulary as used at a temple stele.

\section{The Names for Temples, Altars, and Gates}

Names for temples, altars, and gates were revised as part of the larger overhaul of the prescribed Manchu lexicon. The emperor, the Grand Council, and provincial officials were actively involved in the language reform. In several instances, officials in the field memorialized the throne on language-related issues, seeking clarification on points of vocabulary.

To be sure, deliberations over the Manchu names for public institutions or places did not begin with Qianlong. Already in 1636, Hong Taiji opposed his officials' suggestion that the capital's city gates receive Manchu names translated from their Ming counterparts, e.g., goroki be toktobure duka, "Gate of the ordering of distant places" for Chinese dingyuan men 定遠門. Hong Taiji opposed such allegedly haughty and presumptuous language. He preferred names such as jecen be tuwakiyara duka, "Gate Watching Over the Frontiers," which was the one chosen in this case. ${ }^{38}$

Manchu government sources from the Kangxi and Yongzheng periods contain the names of many of Beijing's city and palace gates as well as of palace buildings. The city gates clearly had established Manchu translations in this period, as they are encountered in the same form in different kinds of sources, even visual ones. ${ }^{39}$ Some palace buildings had established names too. Their names were, like their Chinese counterparts, noun phrases with words like gung (< gong 宮 “palace”) or diyan (< dian 殿 “hall”) as their head, e.g., amba hüwaliyambure diyan for Taihe dian 太和殿. Kangxi-period records contain a few names that are transcriptions from Chinese through and through, e.g., u ing diyan for Wuying dian 武英殿, and these become more common in Yongzhengperiod sources. ${ }^{40}$ The visual depiction of the Kangxi emperor's sixtieth birthday, completed in 1717, shows the wooden decorated archways at Xisi 西四 ${ }^{41}$ in the western part

38. Kicentai, Teikoku o tsukutta gengo seisaku, 98.

39. E.g., the Manchu name for Xizhi men 西直門, tob wargi duka, is seen in Wanshou shengdian chuji 萬壽盛典初集, highresolution digitized copy held at Bibliothèque Nationale de France with the call number Chinois 2314 (Beijing, 1716), 41:73a.

40. Chuang Chi-fa 莊吉發 [Zhuang Jifa], “Qingwen guoyu: Manwen shiliao yu Yongzheng chao de lishi yanjiu” 清文國 語一滿文史料與雍正朝的歷史研究, in Qingshi lunji 清史論集, vol. 20 (Taipei: Wen shi zhe chubanshe, 2010), 11931 .

41. Identification of location from Yū Enpō 熊遠報, “Jūhachi seiki ni okeru Pekin no toshi keikan to jūmin no seikatsu sekai” 18世紀における北京の都市景観と住民の生活世界, Tōyō bunka kenkyūjo kiyo 東洋文化研究所紀要 164 (2013): 228 (figure 9-3). 
of Beijing's inner city as carrying the crossing's street names in Manchu and Chinese. The Manchu names here translate the Chinese rather than transcribe it. ${ }^{42}$ By contrast, when the Yongzheng emperor almost a decade later (1726) donated inscriptions to be hung over the gate to various government offices in the capital, the Manchu text simply transcribed the pronunciation of the Chinese characters. ${ }^{43}$

In the Qianlong period, a prominent goal of the revision of names was to replace such Chinese loans with words having a Manchu-looking morphology. Despite looking like old Manchu words, the replacements enacted under Qianlong were generally neologisms coined for the occasion. Surviving discussions show that the parties involved were very sensitive regarding the origin of words. Chinese was one thing, Manchu another, they thought, and preferably the two should be kept distinct. However, unlike under Hong Taiji, mimicry of the semantics of the corresponding Chinese expression was not an issue. The language could now be as flowery as the Chinese, and mean exactly what the Chinese meant, as long as the words looked Manchu.

Numerous lists with new words remain from the Qianlong period. They were sent by the Imperial Household Department in Beijing to its homolog in Mukden for promulgation there, and they are now partially accessible. The lists tend to focus on a certain theme. In one instance, that theme was public buildings.

Late in 1748 (Qianlong 13/10/22), the Imperial Household Department announced a new installment in the series of new Manchu words. This time, the list included Manchu alternatives to the Chinese loans gung and diyan. There former was fixed as gurung and the latter as deyen — words that retained echoes of the Chinese originals. ${ }^{44}$ Less than a year later (Qianlong 14/7/17), the emperor remarked that "the Manchu text carved on the stele at Anyou 安佑 palace [at the Summer Palace northwest of Beijing] still says gung. Now, since gung . . . has been fixed as gurung, erase . . . the Manchu text gung and replace it ... . with gurung" (an io gung ni eldengge wehe de manju hergen kemuni tere gung ni bei seme folohobi, te gung be gurung . . . seme toktobuha be dahame, da foloho gung ... sere manju hergen be nilafi encu gurung . . . seme niyeceteme folokini). ${ }^{45}$ Qianlong was evidently a force not only in the formulation of the language reform, but also in its enactment.

Shortly after gung and diyan were discontinued, the Grand Council proposed to

42. Wanshou shengdian chuji, 41:25a-26a. I am having trouble reading some of the Manchu in the wood engravings in that source. The painted scroll version reproduced in Gugong bowu yuan 故宮博物院, ed., Putian tong qing: Qingdai wanshou shengdian tulu 普天同庆: 清代万寿盛典图录 (Beijing: Gugong chubanshe, 2015), 84, looks neater, but the reproduction is too small for me to be able to make out the words.

43. Chuang, "Qingwen guoyu," 128-29.

44. Zhang Hong 张虹, Cheng Dakun 程大鲲, and Tong Yonggong 佟永功, eds., "Qianlong chao 'Qinding xin Qingyu' (san)” 乾隆朝“钦定新清语” (三) , Manyu yanjiu 满语研究, no. 2 (1995): 54. The word gurung is used in the title of a stele from 1662 (Kangxi 1) that is listed in Beijing shi minzu guji zhengli chuban guihua xiaozu bangong shi Manwen bianji bu, Beijing diqu Manwen beike tapian zongmu, 302-3 (item 696), but it is not clear from the entry that this word actually figured on the stele itself.

45. Previously cited court letter in 03-18-009-000008-0002, FHA. 
similarly replace the Chinese loanwords tan "altar" and miyoo "temple." They should now be mukdehun and juktehen (cf. the verb juktembi, "to sacrifice, to worship") in Manchu. ${ }^{46}$ Effectuating this change in practice involved making choices for which the officials involved sought imperial guidance.

The uncertainty stemmed from a provision that Qianlong made regarding the use of the new words. In early 1749 (Qianlong 13/12/12), Qianlong, presumably motivated by his aversion to mixing Manchu and Chinese elements, decided to restrict the usage of certain new words. "If Manchu translations exist for the characters that precede $g u$ rung and deyen [in the names of palaces and halls]," Qianlong said,

then they should be called gurung and deyen. If no Manchu translations exist for the Chinese characters, [these places] should still be referred to using their Chinese names, calling them simply diyan and gung.

gurung, deyen-i dergi hergen ubaliyambuha manju gisun bisirengge oci, gurung, deyen seme arakini gung, diyan-i dergi nikan hergen be manju gisun-i ubaliyambuhakūngge oci, kemuni nikan hergen be dahame, an-i gung, diyan seme arakini ${ }^{47}$

When Biyantaha, director of the court of sacrificial worship (wecen-i baita be aliha yamun-i aliha hafan, i.e. Taichang si zhengqing 太常寺正卿), considered the names of the capital's altars and temples, he found that some had names with Manchu equivalents, others not. Temples that, according to Biyantaha, had Manchu names were tian tan 天 壇, the Altar to Heaven, and lidai diwang miao 歷代帝王廟, the Temple to Past Emperors. ${ }^{48}$ They had reportedly already been translated as abkai tan and jalan jalan-i han sei miyoo (with Chinese loans used for "altar" and "temple"). Biyantaha did not point it out, but the latter name is seen on a stele erected at the site in $1733 .{ }^{49}$ The two institutions should now, Biyantaha proposed, receive the new names of abkai mukdehun and jalan jalan-i han sei juktehen. The latter name was indeed subsequently used on a stele erected on the site in $1764 .^{50}$

Biyantaha identified two temples without Manchu names. One was the Daoist Dongyue miao 東岳廟 (dong yo miyoo), the God of the Eastern Peak Temple, located outside the city walls to the east and benefitting from the patronage of bannermen and

46. The two words were included on the list of new terms circulated to the Mukden imperial household department on 1749/3/11 (Qianlong 14/1/23): Zhang, Cheng, and Tong, “Qianlong chao 'Qinding xin Qingyu' (san)," 57-58.

47. Biyantaha, Manchu palace memorial file copy dated Qianlong 13/12/24 (1749/2/11), 03-0170-0105-024, FHA. Also quoted inside a letter transcribed in Zhang, Cheng, and Tong, 57.

48. Susan Naquin, Peking: Temples and City Life, 1400-1900 (Berkeley: University of California Press, 2000), 144-45.

49. Beijing tushuguan, Beijing tushuguan cang Zhongguo lidai shike taben huibian, vol. 68, 128.

50. Beijing shi minzu guji zhengli chuban guihua xiaozu bangong shi Manwen bianji bu, Beijing diqu Manwen beike tapian zongmu, 292 (item 672). 
bannerwomen. ${ }^{51}$ In 1704 (Kangxi 43), a bilingual stele had been erected at the temple (Biyantaha did not mention it), on which the name was written as dergi io-i miyoo, ${ }^{52}$ using precisely the kind of Manchu-Chinese mixed language that Qianlong wanted to avoid (dergi being Manchu, io Chinese). The other institution without a Manchu name was the Altar for Asking for Grain, qigu tan 祈穀壇 (ki ku tan). What should be done with these names? In an apparent intensification of the language reform, Qianlong, in response to Biyantaha's query, ordered all of them translated (gemu ubuliyambukini). ${ }^{53}$ A few months later (Qianlong 14/3/8, 1749/4/24), the Imperial Household Department accordingly announced new Manchu names for several more altars. ${ }^{54}$ Finally, in 1762 (Qianlong 26), a stele was erected at Dongyue miao on which the name was given as dergi colhon-i juktehen. ${ }^{55}$

The temples and altars where the emperor carried out various rituals received new names. Yet they were not, as it were, set in stone. More than thirty years after the institutions had been renamed (Qianlong 46/5/30, 1781/6/21), Fu[lunggan] (1743/461784), memorialized the throne saying that "[Buddhist] temple" (si 寺) and "[Confucian] temple" (miao 廟) were both translated as juktehen. The almost seventy-year-old emperor responded that Buddhist temples should be called juktehen and Confucian ones muktehen, ${ }^{56}$ a word seen as a translation of miao on a stele as early as 1738 (Qianlong 3). ${ }^{57}$ However, three decades earlier, Confucian temples had been juktehen.

As the aging Qianlong emperor's remarks to Fulanggan shows, the revision of names for public places continued beyond Biyantaha's memorials in the late 1740s. For example, in 1764 (Qianlong 29/6/4, 1764/7/2), Qianlong responded to a request by Coociowan, vice-president of the Board of Punishments in Mukden, regarding the Willow Palisade, a system of interior borders intended to protect the Manchu homeland. Coociowan requested that a Manchu name be established for one of the gates in the palisade.

51. Naquin, Peking, 506-17.

52. Beijing tushuguan, Beijing tushuguan cang Zhongguo lidai shike taben huibian, vol. 66, 65.

53. Biyantaha, 03-0170-0105-024, FHA.

54. Zhang Hong 张虹, Cheng Dakun 程大鲲, and Tong Yonggong 佟永功, eds., “Qianlong chao 'Qinding xin Qingyu' (si)” 乾隆朝“钦定新清语”（四）, Manyu yanjiu 满语研究, no. 2 (1996): 33.

55. Beijing shi minzu guji zhengli chuban guihua xiaozu bangong shi Manwen bianji bu, Beijing diqu Manwen beike tapian zongmu, 291 (item 670).

56. Zhang Hong 张虹, Cheng Dakun 程大鲲, and Tong Yonggong 佟永功, eds., “Qianlong chao 'Qinding xin Qingyu' (shi)” 乾隆朝“钦定新清语” (十), Manyu yanjiu 满语研究, no. 2 (2004): 74. The author of the memorial held the title tondo baturu gung, viz. zhongyong gong 忠勇公. Zhang et al. transcribe his name, given as fu in Manchu, as $f u$ 傅, thinking perhaps that it refers to Fuheng, who held this title. But Fuheng was dead at this time. His son, Fulunggan 福隆 安, inherited the title. I conjecture that Fulunggan was the author of the memorial. See Fang Chao-ying, "Fu-Lung-An," in Eminent Chinese of the Ching Period (1644-1912), ed. Arthur W. Hummel, vol. 1, 2 vols. (Washington, D.C.: United States Government Printing Office, 1944), 259-60. For the Manchu spelling of his name, see Beijing shi minzu guji zhengli chuban guihua xiaozu bangong shi Manwen bianji bu, Beijing diqu Manwen beike tapian zongmu, 228-29.

57. Beijing shi minzu guji zhengli chuban guihua xiaozu bangong shi Manwen bianji bu, Beijing diqu Manwen beike tapian zongmu, 281-82 (item 648). Also in 1740: 282 (item 649). 
Coociowan's request was not unique. In the 1720s, a certain Maitu, who had travelled to Tibet, complained that signs along the empire's roads, borders, and city gates and passes did not carry Manchu inscriptions. ${ }^{58}$ In Coociowan's case, there was at least Manchu text on the gate. The problem was that the Manchu simply transcribed the Chinese.

The gate whose name Coociowan wanted to change was called Weiyuan Bao 威遠 堡 “Fortress” after an old Ming-era installation (in late Qing times just a gate). Unlike the gates of Xingjing 興京 (called Yenden in Manchu), Aiyang 震陽 (called Aiha), and that of the walled city of Fenghuang 鳳凰城 (called Fucaha), the gate at Weiyuan Bao was simply called Wei juwan beo in Manchu in a transcription of the Chinese name. The imperial decision was to give Weiyuan Bao the Manchu name goroki de horon tuwabure jase, "Gate of Far-Reaching Display of Might."

The new name for Weiyuan Bao, which was a translation of the Chinese name rather than its phonetic transcription, was acceptable and considered to be properly Manchu in the context of the Qianlong reforms. Yet the choice contrasts markedly with the names of gates chosen under Hong Taiji, as discussed above. In 1636, a name similar to goroki horon tuwabure jase, to wit goroki be toktobure duka, had been rejected in favor of a more down-to-earth term.

The renaming of Weiyuan Bao is an example of how Qianlong-era language reform affected places that lay outside the capital city and carried inscriptions that would have been seen by many people-in this case, travelers in Manchuria. It is also, similarly to Bianta's proposals for imperial temples and altars, an example of an official proposing to change a name on his own initiative, which suggests that it was not just Qianlong himself who was bothered by Chinese words hiding in Manchu transcription.

In other respects, Coociowan's memorial is puzzling. Some of the place names he contrasted with Wei yuan beo, such as the pairs Xingjing/Yenden and Fenghuang/ Fucaha, were fairly straightforward. They were cases in which one name was morphologically Chinese and the other represented a local, non-Chinese tradition. In so far as those local names were used in Manchu, they can certainly be called Manchu names, but it is possible that they were older place names that had entered Manchu usage from whatever language was originally spoken in the area (a possibility that Coociowan, unsurprisingly, did not consider). Other name pairs that Coociowan mentioned, however, do not contrast with Weiyuan Bao/Wei yuan beo as clearly. Alongside Xingjing and Fenghuang, Coociowan mentioned the Manchu name Giyamcan for the palisade gate that in Chinese was called Xianchang 鹹廠. Probably speaking a form of Mandarin relatively similar to the one used today, Coociowan did not see that Giyamcan is a loan either from a local Chinese dialect or, in case it dated from a much earlier period,

58. Mark C. Elliott, The Manchu Way: The Eight Banners and Ethnic Identity in Late Imperial China (Stanford: Stanford University Press, 2001), 295-96. 
from Middle Chinese ( $\gamma$ ə⿱亠䒑十t $\left.\zeta^{h} a \eta\right) .{ }^{59}$ In southern Manchuria, speakers of Chinese and Tungusic languages had interacted for a long time and the languages shared some vocabulary; clearly, more than Coociowan was aware of or would admit. ${ }^{60}$

I should note, moreover, that Coociowan was not bothered by cases in which there was no proper Chinese name. Alongside Xingjing and Fenghuang, he mentioned, for example, Ying'e 英額 and its Manchu counterpart Yengge. In this case, the Chinese is an obvious transcription of the Manchu, but that was no reason to change it. ${ }^{61}$

The overhaul of the names of palace buildings and government structures thus continued for much of the eighteenth century and involved both the emperor and his officials. The names were used even into the nineteenth century, if not necessarily in inscriptions. The 1655 (Shunzhi 11/12) Manchu translation of the Classic of Poetry (Shijing 詩經) had miyoo and gung for Chinese miao and gurung. By contrast, the revised version from 1768, which circulated much more widely, used juktehen for miao and gurung for gong. ${ }^{62}$ Furthermore, the various gurung, deyen, muktehun, muktehen, and other institutions are listed in a commercially published collection of "names of the boards and government offices" (Ma. jurgan yamun-i gebu; Ch. yashu mingmu 衙署名 目) from $1889 .{ }^{63}$

However, the efforts invested in the project notwithstanding, when photographed in the 1920s, many palace gates and buildings in Beijing carried Manchu names that were but transcriptions of their Chinese counterparts. Qianlong's neologism gurung for "palace" was seen, but the old transcription gung was more common. ${ }^{64}$ Similarly, when a traveler through the Weiyuan bao gate reported in in 1886 that a tablet with the name was hung on the gate, he made no mention of a Manchu inscription there. ${ }^{65}$ Perhaps the Qianlong neologisms survived in government documents, but not always in public inscriptions.

59. Edwin G. Pulleyblank, Lexicon of Reconstructed Pronunciation in Early Middle Chinese, Late Middle Chinese, and Early Mandarin (Vancouver: UBC Press, 1991), 50, 335.

60. Schmidt, "Chinesische" (first article), 574 remarked that Qianlong's court scholars were probably not aware of many of the early Chinese loans in Manchu.

61. Coociowan, Manchu palace memorial file copy, 03-0181-2088-022, FHA, rescript dated Qianlong 29/6/4 (1764/7/2).

62. Kim Chu-wŏn 김주원, Ko Tong-ho 고동호, and Chŏng Che-mun 정제문, "Manmun Sigyŏng ŭ pŏnyŏk yangsang yŏn'gu” 滿文 詩經＼cjkstart眽譯樣相 研究, Al'tai hakpo 알타이학보 19 (2009): 21.

63. Qingyu zhaichao 清語摘鈔, microfilm of the copy held at Tenri Library with the call-number 829.44-9 (Beijing: Juzhen Tang, 1889), vol. 4. The volumes are not numbered. I follow the order given in Kawachi Yoshihiro 河内良弘 and Zhao Zhan 趙展, “Tenri Toshokan zō Manbun shoseki mokuroku” 天理図書館蔵満文書籍目録, Biblia ビブリア 84 (1985): 172.

64. Hartmut Walravens, "Mandjurisches. I.,” Ural-Altaische Jahrbücher, new series, 7 (1987): 241-42.

65. Nagayama Takeshirō 永山武四郎, Shūyū nikki 周遊日記, vol. 2 (Sapporo: Tondenhei honbu, 1889), 237; Richard L. Edmonds, "The Willow Palisade," Annals of the Association of American Geographers 69, no. 4 (1979): 616. 
The Inscription at Fragrance of the Teaching Temple

Revising the words used on inscriptions did not just involve the names for the institutions that the inscriptions commemorated, but also words used in the main body of longer inscriptions. I will discuss an example involving the establishment of Manchu vocabulary for Buddhist deities in the context of translation from Mongolian.

When workers on Qianlong's order erected a Temple of True Victory (Ma. yargiyan etehe juktehen; Ch. shisheng si 實勝寺) in the hills in Beijing's western suburbs, they found a dilapidated temple nearby. The emperor ordered it restored, gave it the name Fragrance of the Teaching Temple (Ma. šajingga wangga juktehen; Ch. fanxiang si 梵 香寺) and erected two steles at the site. The first carried a Manchu inscription on one side and Mongolian on the other. The second carried a Chinese inscription on one side, and, reportedly, "Sanskrit" (Fanwen 梵文) on the other. ${ }^{66}$ Rubbings of the three first inscriptions have been published, but especially the Chinese text is damaged, showing a diagonal crack through the whole slab. Perhaps the Sanskrit (not Tibetan?) text was illegible, which might explain that no rubbing was made of it.

The restoration of the temple reflects Qing court policy. The Temple of True Victory was erected upon the conclusion of the First Jinchuan Campaign, Qianlong's war with Tibetan or Gyalrong-speaking tribes in western Sichuan. ${ }^{67}$ That a Buddhist temple should be erected right next to one that celebrated the purported military successes of the empire indeed shows that the court continued to rely on Buddhism, so important in the Qing's new Western possessions, to mediate its relationship with the Tibetans and Mongols, and that inscribed steles played an important part in that process.

Yet the steles were also part of a larger project of producing Buddhist texts at court. As early as 1742, Qianlong's Buddhist teacher Rolpai Dorje (1717-1786) ${ }^{68}$ headed the project to translate the Tanjur from Tibetan to Mongolian, a project that finished shortly before the Fragrance of the Teaching Temple steles were erected. ${ }^{69}$ Translation of sutras into Manchu had evidently begun already at this time, although the most famous project of Manchu Buddhist translation, that of the Kanjur, dates to a few decades later. Buddhist terminology in Manchu was created as a result, but at the time of the erection of the Fragrance of the Teaching Temple steles, that terminology was not yet well established.

An archival document shows that before the stele was carved, officials in the Grand Council revised the wording of the Manchu text. The document implies that at least

66. Beijing tushuguan, Beijing tushuguan cang Zhongguo lidai shike taben huibian, vol. 70, 121.

67. Yingcong Dai, The Sichuan Frontier and Tibet: Imperial Strategy in the Early Qing (Seattle: University of Washington Press, 2009), 126-29.

68. Elliott, Emperor Qianlong, 73-74.

69. Walther Heissig, Die Pekinger lamaistischen Blockdrucke in mongolischer Sprache. Materialien zur mongolischen Literatur5rgeschichte (Wiesbaden: Harrassowitz, 1954), 96. 
parts of the Manchu text were translated from Mongolian. The document gives a hint of the process by which multilingual stele were produced at the Qianlong court.

An official-Fuheng (1721-1770) $?^{70}$ —memorialized (Qianlong 14/11/23, $1750 / 1 / 1)$ the throne and remarked on a few errors that had crept into the text that was to be inscribed on the stele at Fragrance of the Teaching Temple. ${ }^{71}$ Fuheng, if it was him, had been ordered by Qianlong to look over the text that was to be carved onto the stele. He found several problems relating to how Mongolian Buddhist vocabulary had been rendered into Manchu. The names of Buddhist deities had been carried over into Manchu with their Mongolian pronunciation nearly intact. But just as obvious Chinese loans in Manchu were a problem, so were obviously Mongolian loans. ${ }^{72}$ Fuheng wrote:

Acting on an edict. Upon examination, [it was found that] the expression kiciyenggui [i.e., Mo. kičiyenggüi] has been translated as kicen "effort" [<Skt. virrya, corresponding to Ch. jing 精73] in the Manchu-language versions of the sutras. [In the text to be inscribed] on the stele at the Fragrance of the Teaching Temple, it has been erroneously written as kiciyangkui. [I,] your official fixed it as kicen according to the translated sutras and pasted it on a yellow slip.

Besides, examining it again, [it was found] that in the Manchu-language version of the sutras, in order to give an equivalent for bodisadu and mahasadu, the words had been repeated as in the Mongolian original. Taken separately, bodisadu translates as fusa and mahasadu as "great fusa" (amba fusa) [i.e. Mahāsattva]. The text of the stele contains the expression binwat gaijara bodisadu, "Bodhisattva who obtains binwat." Even though binwat,"alms" [from Mo. binvad and ultimately from Skrt. pinda-pāta] $]^{74}$ does not have a Manchu translation, [the expression] can be written as "The fusa who obtains the binwat of truth." Continuing to write bodisadu is not appropriate. I establish fusa for bodisadu and paste it on a yellow slip, respectfully passing it along for consideration.

hese be dahame, kiciyenggui sere gisun be baicaci, manjurame ubaliyambuha nomun de, kiciyenggui be kicen seme ubaliyambuha, šajingga wangga juktehen-i eldengge wehei bithei dorgi, kiciyangkui seme arahangge tašarahabi, amban be manjurame ubaliyambuha

70. The catalog at the First Historical Archives gives Fuheng as the author of the memorial, but his name does not appear in the Manchu text of the memorial.

71. Beijing shi minzu guji zhengli chuban guihua xiaozu bangong shi Manwen bianji bu, Beijing diqu Manwen beike tapian zongmu, 285 (item 656).

72. Notwithstanding the fact that a significant part of the Manchu vocabulary consists of older Mongolian borrowings that apparently did not appear as such to Fuheng.

73. Erich Hauer, Handwörterbuch der Mandschusprache, edited by Oliver Corff, $2^{\text {nd }}$ edition (Wiesbaden: Harrassowitz, 2007), 307.

74. Ferdinand D. Lessing et al., comps., Mongolian-English Dictionary (Berkeley: University of California Press, 1960), 1163, sub voce binvad. 
[nomun]-i gisun-i songkoi kicen seme dasafi suwayan afahari latubuhaci tulgiyen, geli baicaci, manjurame ubaliyambuha nomun de, bodisadu mahasadu be holbome araci, an-i monggo hergen-i songkoi bodisadu mahasadu seme arambi, aika faksalame araci, bodisadu be fusa, mahasadu be amba fusa seme ubaliyambuhabi, ere eldengge wehei bithei dorgi binwat gaijara bodisadu sere gisun be, binwat udu manju gisun-i ubaliyambuhakü bicibe giyan-i binwat gaijara fusa seme araci acambi, kemuni bodisadu seme arahangge, inu acanaraku, bodisadu be jusa seme dasafi, suwayan afahari latubufi suwaliyame gingguleme tuwabume wesimbuhe,

To avoid divergent translations such as the one on the stele, Qianlong agreed with the memorialist that "all Mongolian- and Tibetan-script expressions that have not been translated in the Manchu-language version of the sutras shall be sent to Prince Zhuang of the First Rank [i.e., Yūn lu 允祿 (1695-1767)], who will translate them together with the living Buddha [i.e., Rolpai Dorje]" (manjurame ubaliyambuha nomun de bisire ubaliyambuhakū monggo, tanggüt hergen-i gisun be, tob cin wang de afabufi, janggiya kūtuktu-i ${ }^{75}$ emgi inu manjurame ubaliyambukini). ${ }^{76}$

It appears that the stele was only erected after this exchange took place. The text is dated to an "auspicious day" (Ma. sain inenggi; Ch. jiri 吉日) in Qianlong 14/11 (1749/12/10-1750/1/7), which must have been no more than a week after Fuheng's memorial, if the date is accurate. Interestingly, the Manchu text that was actually carved on the stele does not contain the phrase giyan-i binwat gaijara fusa, "The Bodhisattva who obtains binwat." The inscription does, however, contain the sentence:

In the past, the Buddha told Śūra and Mahāsattva to practice and study the Lotus sutra.

seibeni fucibi, kicen fusa, amba fusa de alame, šu ilhai enduringge nomun be urebume tacifi, ${ }^{77}$

In the Mongolian inscription, Śūra and Mahāsattva are indeed referred to as kičiyenggüi bodisadu and mahasadu. In the Chinese, they are jingjin pusa 精進菩薩 and mohesa 摩 訶薩 ${ }^{78}$ The full Chinese name for Súra is not, as in the inscription, jingjin pusa, but da jingjin pusa, with da 大 meaning "great." Perhaps the full name was not used on the stele for lack of space. That the established Manchu translation for Süra is "great Bodhisattva," however, suggests that even in the case of translation from Mongolian (mahasadu), the semantic structure of the corresponding Chinese expression (da jingjin

75. From the Mo. janggiy-a qutuy-tu.

76. [Fuheng?], Manchu palace memorial file copy dated 24/11/23 (Qianlong 1760/1/10), 03-0174-1521-001, FHA.

77. Beijing tushuguan, Beijing tushuguan cang Zhongguo lidai shike taben huibian, vol. 70, 121.

78. Beijing tushuguan, Beijing tushuguan cang Zhongguo lidai shike taben huibian, vol. 70, 122-23. 
pusa) still played a part in the coining of the Manchu expression. Furthermore, as in the case of Coociowan's names for gates in the Willow Palisade, Fuheng here was unaware of - or at least not bothered by - the fact that fusa represented an early loan from the Chinese pusa (the change from $p$ - to $f$ - in loans from that period being regular). ${ }^{79}$

Finally, the fact that binwat does not appear on the stele suggests that the inscription was revised further even after Fuheng's memorial. Clearly, erecting a stele even in a relatively peripheral mountainous location was not a small matter, especially if it was plurilingual and contained specialized vocabulary. At this time, Buddhist vocabulary in Manchu was not yet definitely fixed, which meant that Qianlong's officials and religious advisors had to make choices as they went along. Yet because of the attention paid to language in this period, the choices were subject to revision.

After the erection of this stele, the court eventually produced quadrilingual collections that standardized Buddhist vocabulary in Tibetan, Mongolian, Manchu, and Chinese. ${ }^{80}$

\section{Conclusion}

The overview of the Qing government's public Manchu inscriptions from the preconquest period to the second half of the eighteenth century that I have given in this paper shows that steles and signs with Manchu text were complicated but important to the court and its servants. Manchu steles announced government policy, and the language's use on public buildings asserted the power of the dynasty. The frequent back-and-forths between the court and officials in the field give a sense of the costly and complicated logistics involved in sourcing stones of the size needed for plurilingual inscriptions, establishing and sending out the text, and allocating the skilled manpower needed to execute the work. My sources show that erecting Manchu steles, which almost always contained other languages as well, was a major undertaking.

The sources used in this paper do not show how the new steles were received. Such sources might very well exist, however. Notably, I have largely left untouched the stele erected to commemorate Manchus, for which officials petitioned the throne. Such steles and the sources surrounding them would be a good place to start for looking at interaction between the court and the communities that would have read, looked at, or otherwise interacted with Manchu steles. This work has already been done, for example, for the commemorative arches for chaste widows erected, with government sanction,

79. P[eter] Schmidt, "Chinesische Elemente im Mandschu. Wörterverzeichnis (Fortsetzung)," Asia Major, first series, 8 (1933): 239.

80. Tatiana A. Pang, ed. Schriftliche mandschurische Quellen zur Geschichte und Kultur des Qing-Reiches des 17. und 18. Jahrhunderts, translated by Giovanni Stary and Hartmut Walravens, Abhandlungen für die Kunde des Morgenlandes 100 (Wiesbaden: Harrassowitz, 2015), 87. 
by the local Chinese elite in Huizhou. ${ }^{81}$ Yet even with this work still left undone, I can confidently say that the kind of public inscriptions discussed here were seen by large numbers of people and that, given the evident financial investment and advanced craftsmanship that they represented, they did not go unnoticed.

Given the financial and logistical stakes involved in erecting Manchu steles, it is not surprising that there is a great deal of evidence to suggest that, at least in the eighteenth century, emperor and officials paid great attention to the appropriateness of the Manchu text that were inscribed on them. The Manchu text should not appear as a calque of either Chinese or Mongolian. In the many new contexts in which Manchu was used - as a medium for Buddhist discourse, or on buildings of a kind the Manchus had not possessed when they first wrote down their language in the early seventeenth century-therefore required the development of new terminologies. The execution of the inscriptions, carving on stone, should furthermore be free from errors. In many cases, the will to avoid infelicities and errors led to the commissioning of new inscriptions, as was, we must infer, the result of the approved name revisions discussed above. In other cases, fear of mistakes precipitated avoiding making a Manchu inscription at all, as in government steles in the south in the 1760s.

Yet at least in Beijing and parts of the Northeast, city dwellers and travelers were witnessing a changing inscribed environment of new "shining stones" and repainted signs. Perhaps they, like Fuhai in Lao She's novel, glanced on them out of the corner of their eye at the distance appropriate for such stately embodiments of the dynasty. Accordingly, when the empire weakened and fell, signs were changed, and stele faced neglect or even destruction. Today, much of the evidence remains only on paper-as rubbings, government documents, or printed books—-rather than on the stone that at the time probably appeared much more durable.

\section{Bibliography}

\section{Archival collections:}

Endorsed Manchu palace memorials, Manchu palace memorials file copies, Manchu court letters. First Historical Archives (FHA), Beijing.

\section{Published sources:}

Beijing shi minzu guji zhengli chuban guihua xiaozu bangong shi Manwen bianji bu 北京市民族古 籍整理出版规划小组办公室满文编辑部, ed. Beijing diqu Manwen beike tapian zongmu 北京

81. Yulian Wu, “Let People See and Be Moved': Stone Arches and the Chastity Cult in Huizhou during the High Qing Era,” Nan Nü 17 (2015): 117-63. 
地区满文碑刻拓片总目. Beijing diqu shaoshu minzu guji mulu congshu 6. Shenyang: Liaoning minzu chubanshe, 2015.

Beijing tushuguan 北京圖書館. Beijing Tushuguan cang Zhongguo lidai shike taben huibian 北京圖書 館藏中國歷代石刻拓本匯編. Zhengzhou: Zhengzhou guji chubanshe, 1989-1991.

Ch'oe Hak-kŭn 崔鶴根. “Sowi ‘Samjŏndo-bi' ŭi Manmun pimun chuyǒk” 所謂「三田渡碑」의 滿 文碑文 註譯. In his Chüngbo Altaiǒhak non'go: Munhŏn kwa munbŏp 增補알타이語學論放一 文獻과文法, 8-37. Ed. Yi Hŭi-sŭng 李熙昇. Seoul: Pogyŏng munhwasa, 1989.

Chuang Chi-fa 莊吉發 [Zhuang Jifa]. “manju hergen - manju gisun-Manzhou yuwen zai Qingchao lishi wutai shang suo banyan de juese” manju hergen - manju gisun一滿洲語文在清朝歷史舞 臺上所扮演的角色. In Qingshi lunji 清史論集, vol. 23. Taipei: Wen shi zhe chubanshe, 2013. —. “Qingwen guoyu: Manwen shiliao yu Yongzheng chao de lishi yanjiu” 清文國語—滿文 史料與雍正朝的歷史研究, in Qingshi lunji 清史論集, vol. 20, 117-218. Taipei: Wen shi zhe chubanshe, 2010.

—, trans. Sun Wencheng zouzhe 孫文成奏折. Taipei: Wen shi zhe chubanshe, 1978.

Crossley, Pamela Kyle, and Evelyn S. Rawski. "A Profile of the Manchu Language in Ch'ing History." Harvard Journal of Asiatic Studies 53, no. 1 (1993): 63-102.

Dai, Yingcong. The Sichuan Frontier and Tibet: Imperial Strategy in the Early Qing. Seattle: University of Washington Press, 2009.

Edmonds, Richard L. "The Willow Palisade." Annals of the Association of American Geographers 69, no. 4 (1979): 599-621.

Elliott, Mark C. Emperor Qianlong: Son of Heaven, Man of the World. New York: Longman, 2009.

. The Manchu Way: The Eight Banners and Ethnic Identity in Late Imperial China. Stanford: Stanford University Press, 2001.

—_. "Turning a Phrase: Translation in the Early Qing Through a Temple Inscription of 1645." In Martin Gimm, Giovanni Stary, and Michael Weiers, ed. Historische und bibliographische Studien zur Mandschuforschung, 12-41. Aetas Manjurica 3, 1992.

Fang Chao-ying. "Fu-Lung-An.” In Arthur W. Hummel, ed. Eminent Chinese of the Ching Period (16441912), vol. 1, 259-60. Washington, D.C.: United States Government Printing Office, 1944.

Fuchs, Walter. "Early Manchurian Inscriptions in Manchuria." The China Journal 15 (1931): 5-9.

Gaozong Chun huangdi shilu 高宗純皇帝實錄. Qing shilu. Beijing: Zhonghua Shuju, 1986.

Gugong bowu yuan 故宮博物院, ed. Putian tong qing: Qingdai wanshou shengdian tulu 普天同庆: 清代万寿盛典图录. Beijing: Gugong chubanshe, 2015.

Guan Xiaojing 关笑晶. “Qing qianqi Beijing simiao Manwen bei chutan” 清前期北京寺庙满文 碑初探. In Zhao Zhiqiang 赵志强, ed., Manxue luncong 满学论丛, vol. 4. Shenyang: Liaoning minzu chubanshe, 2014.

Guang-lu 廣祿 and Li Xuezhi 李學智, trans. Qing Taizu chao lao Manwen yuandang: Di er ce “ze" zi lao Manwen dangce 清太祖朝老滿文原檔: 第二冊员字老滿文檔冊. Taipei: Taiwan zhonghua shuju, 1970.

Guang-lu 廣祿 and Li Xuezhi 李學智, trans. Qing Taizu chao lao Manwen yuandang: Di yi ce "buang” zi lao Manwen dangce 清太祖朝老滿文原檔：第一冊荒字老滿文檔冊. Taipei: Taiwan zhonghua shuju, 1970.

Guoli gugong bowuyuan 國立故宮博物院, ed. Gongzhong dang Kangxi chao zouzhe 宮中檔康熙朝 奏摺. Vol. 9. Pt. 2. Taipei: Guoli gugong bowuyuan, 1976-1977.

Guoli gugong bowuyuan 國立故宮博物院, ed. Gongzhong dang Qianlong chao zouzhe 宮中檔乾隆朝 奏摺. Taipei: Guoli gugong bowuyuan, 1982-1988.

Han-i araha manju gisun-i buleku bithe. Beijing: Wuying Dian, 1708.

Hauer, Erich. Handwörterbuch der Mandschusprache. Edited by Oliver Corff. $2^{\text {nd }}$ edition. Wiesbaden: Harrassowitz, 2007. 
Heissig, Walther. Die Pekinger lamaistischen Blockdrucke in mongolischer Sprache. Materialien zur mongolischen Literaturgeschichte. Wiesbaden: Harrassowitz, 1954.

Jiu Manzhou dang yizhu: Qing Taizong chao (yi) 舊滿洲檔譯註: 清太宗朝（一). Taipei: Guoli gugong bowu yuan, 1977.

Kam, Tak-Sing. "The Sino-Manchu Inscription of 1630 in Honour of the Uluk Darxan Nangsu Lama." International Journal of Central Asian Studies 4 (1999): 217-40.

Kawachi Yoshihiro 河内良弘 and Zhao Zhan 趙展. “Tenri Toshokan zō Manbun shoseki mokuroku” 天理図書館蔵満文書籍目録. Biblia ビブリア 84 (1985): 184-56.

Kim Chu-wŏn 김주원, Ko Tong-ho 고동호, and Chŏng Che-mun 정제문. "Manmun Sigyŏng ŭ pŏnyŏk yangsang yŏn'gu” 滿文詩經의矍譯樣相研究. Al'tai hakpo 알타이학보 19 (2009): 3158.

Kicentai 庄声 [Zhuangsheng]. Teikoku o tsukutta gengo seisaku: Daichin gurun shoki no gengo seikatsu to bunka 帝国を創った言語政策—ダイチン「グルン初期の言語生活と文化. Kyōto: Kyōto daigaku gakujutsu shuppankai, 2016.

Lao She. Beneath the Red Banner. Translated by Don J. Cohn. Beijing: Panda Books, 1982.

Lao She 老舍. Zhenghong qi xia; Er Ma 正红旗下「二马. Lao She wenji. 1961-1962. Repr., Chongqing: Chongqing chubanshe, 2017.

Lessing, Ferdinand D., Mattai Haltod, John Gombojab Hangin, and Serge Kassatkin, comps. Mongolian-English Dictionary. Berkeley: University of California Press, 1960.

Liu Xiaomeng 刘小萌. Qingdai Beijing qiren shehui 清代北京旗人社会. Beijing: Zhongguo shehui kexue chubanshe, 2008.

Nagayama Takeshirō 永山武四郎. Shūyu nikki 周遊日記. Sapporo: Tondenhei honbu, 1889.

Naquin, Susan. Peking: Temples and City Life, 1400-1900. Berkeley: University of California Press, 2000.

Oshibuchi Hajime 鴐淵一. Manshū hiki kō 満洲碑記考. Tōkyō: Meguro shoten, 1943.

Pang, Tatiana A., ed. Schriftliche mandschurische Quellen zur Geschichte und Kultur des Qing-Reiches des 17. und 18. Jahrhunderts. Translated by Giovanni Stary and Hartmut Walravens. Abhandlungen für die Kunde des Morgenlandes 100. Wiesbaden: Harrassowitz, 2015.

Pang, Tatiana A., and Giovanni Stary. Manchu versus Ming: Qing Taizu Nurhacis "Proclamation to the Ming Dynasty."Wiesbaden: Harrassowitz, 2010.

Pulleyblank, Edwin G. Lexicon of Reconstructed Pronunciation in Early Middle Chinese, Late Middle Chinese, and Early Mandarin. Vancouver: UBC Press, 1991.

Qingyu zhaichao 清語摘鈔. Microfilm of the copy held at Tenri Library with the call-number 829.449. Beijing: Juzhen Tang, 1889.

Rawski, Evelyn S. The Last Emperors: A Social History of Qing Imperial Institutions. Berkeley: University of California Press, 1998.

Schmidt, P[eter]. "Chinesische Elemente im Mandschu. Mit Wörterverzeichnis." Asia Major, first series, 7 (1932): 573-628.

—_. "Chinesische Elemente im Mandschu. Wörterverzeichnis (Fortsetzung)." Asia Major, first series, 8 (1933): 233-76.

Sŏng Paeg-in 成百仁. “Samjŏndo-bi Manjumun”三田渡碑滿洲文. Tong’a munhwa 東亞文化 9 (1970): 117-48.

Taizong Wen huangdi shilu 太宗文皇帝實錄. Qing shilu. Beiijing: Zhonghua shuju, 1986.

Walravens, Hartmut. "Mandjurisches. I." Ural-Altaische Jahrbücher, new series, 7 (1987): 241-51.

Wanshou shengdian chuji 萬壽盛典初集. High-resolution digitized copy held at Bibliothèque Nationale de France with the call number Chinois 2314. Beijing, 1716.

Wu, Yulian. "'Let People See and Be Moved': Stone Arches and the Chastity Cult in Huizhou during the High Qing Era." Nan Nü 17 (2015): 117-63. 
Yū Enpō 熊遠報. “Jūhachi seiki ni okeru Pekin no toshi keikan to jūmin no seikatsu sekai” 18世紀に おける北京の都市景観と住民の生活世界, Tōyo bunka kenkyūjo kiyo 東洋文化研究所紀要 164 (2013): 205-70.

Zach, Erwin von. "Einige Ergaenzungen zu Sacharow's Mandžursko-russki slovarj.” Mitteilungen der deutschen Gesellschaft für Natur- und Völkerkunde Ostasiens 14, no. 1 (1911): 1-116.

—. "Ueber Wortzusammensetzungen im Mandschu." Wiener Zeitschrift für die Kunde des Morgenlandes 11 (1897): 242-248.

Zakharov, Ivan Il'ich. "History of the Manchu Language, from the Preface to Professor I. Zacharoff's Manchu-Russian Dictionary, 1875 [Part 2]." Translated by M. F. A. Fraser. The Chinese Recorder 22, no. 4 (1891): 149-57.

Zhang Hong 张虹, Cheng Dakun 程大鲲, and Tong Yonggong 佟永功, eds. “Qianlong chao 'Qinding xin Qingyu’ (san)” 乾隆朝“钦定新清语” (三). Manyu yanjiu 满语研究, no. 2 (1995): $51-58$.

—. “Qianlong chao 'Qinding xin Qingyu' (shi)”乾隆朝“钦定新清语”（十）. Manyu yanjiu 满语研究, no. 2 (2004): 66-76.

. “Qianlong chao 'Qinding xin Qingyu' (si)” 乾隆朝“钦定新清语”（四）. Manyu yanjiu 满 语研究, no. 2 (1996): 31-38.

Zhongguo di yi lishi dang'an guan 中国第一历史档案馆, ed. Kangxi chao Manwen zhupi zouzhe quanyi 康熙朝满文朱批奏折全译. Beijing: Zhongguo shehui kexue chubanshe, 1996.

Zhongguo di yi lishi dang'an guan 中国第一历史档案馆. Qianlong chao Manwen jixin dang yibian 乾 隆朝满文寄信档译编. Changsha: Yuelu shushe, 2011.

Zhongguo di yi lishi dang'an guan 中国第一历史档案馆, trans. Qing chu nei guoshi yuan Manwen dang'an yibian 清初内国史院满文档案译编. Beijing: Guangming ribao chubanshe, 1989. 
